\title{
EGFR NP_005219.2:p.L747_A750del
}

National Cancer Institute

\section{Source}

National Cancer Institute. EGFR NP 005219.2:p.L747 A750del. NCI Thesaurus. Code C98552.

A deletion of four amino acids from the epidermal growth factor receptor protein from the leucine at position 747 through the alanine at position 750 . 